
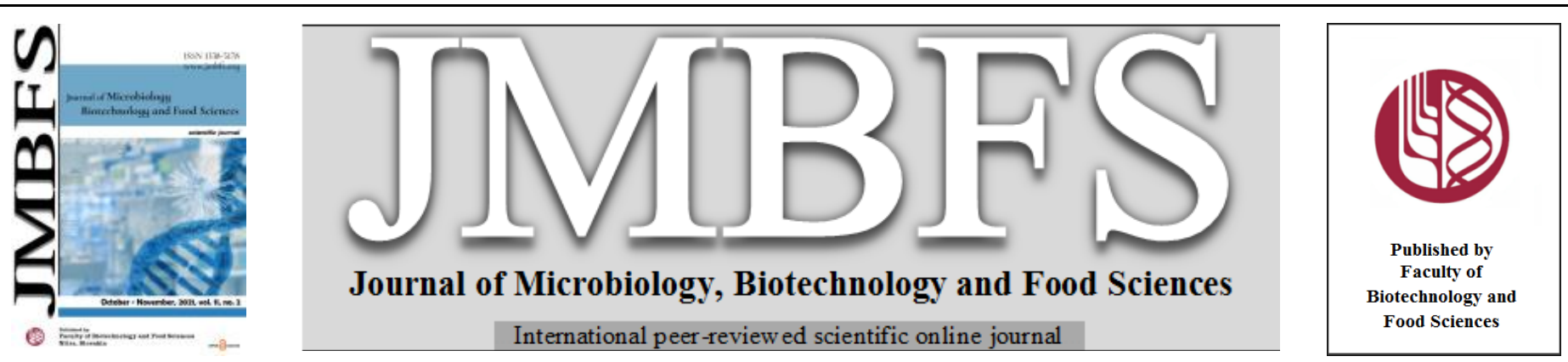

\title{
APPLICATION OF D-OPTIMAL MIXTURE DESIGN AND ARTIFICIAL NEURAL NETWORK IN OPTIMIZING THE COMPOSITION OF FLOURS FOR PREPARATION OF GLUTEN-FREE BREAD
}

\author{
Dileswar Pradhan, Monjurul Hoque, Sushil Kumar Singh, Madhuresh Dwivedi*
}

\section{Address(es):}

Department of Food Process Engineering, National Institute of Technology Rourkela, Rourkela, Odisha, 769008, India.

*Corresponding author: madhureshd@gmail.com / dwivedim@nitrkl.ac.in

https://doi.org/10.15414/jmbfs.3294

\section{ARTICLE INFO}

Received 18. 6. 2020

Revised 16. 4. 2021

Accepted 23. 4. 2021

Published 1. 10. 2021

\section{Regular article}

OPEN $\partial$ ACCESS

\begin{abstract}
D-optimal Mixture Design (DMD) combined with Numerical optimization (NO) and Artificial Neural Network (ANN) combined with Genetic Algorithm (GA) were used in this study to optimize the proportions of pearl millet flour (PMF), red lentil flour (RLF), and mung bean flour (MLF) for preparing gluten-free bread. Based on the value of mean squared error, absolute average deviation and coefficient of determination, the ANN model was found superior to DMD models in predicting the value of responses. The optimum composition of flour obtained using the DMD method was $69.44 \mathrm{~g}$ of PMF, $21 \mathrm{~g}$ of RLF and $9.56 \mathrm{~g}$ of MLF, whereas using the ANNGA technique, it was $68.25 \mathrm{~g}$ of PMF, $23.12 \mathrm{~g}$ of RLF and $8.63 \mathrm{~g}$ of MLF. Sensory analysis indicated that the bread prepared using these two compositions were in the "like slightly" category in terms of overall acceptability.
\end{abstract}

Keywords: Bread; Mixture design; Artificial Neural Network; Genetic algorithm; Optimization

\section{INTRODUCTION}

In India, around 4 million tons of bread is manufactured annually according to the All India Bread Manufacturer's Association (AIBMA). The bread industry is comprised of organized and unorganized sectors, which contribute about $45 \%$ and $55 \%$ of total production respectively. Consumption patterns in southern states, western states, northern states, and eastern states are $32 \%, 27 \%, 23 \%$, and $18 \%$ respectively (AIBMA). As the demand for bread having good nutritive value is increasing among consumers, several efforts have been made for developing bread, which provides health benefits (Bhol \& Bosco, 2014). Refined wheat flour is the main ingredient that is used to prepare bread as it contains gluten (Kaur, 2018, Murkonda \& Dwivedi, 2020). Gluten is responsible for elastic properties of dough (Gallagher, Gormley, \& Arendt, 2004). But, people having the celiac disease are intolerant of this protein (Deora, Deswal, Dwived \& Mishra, 2014; Dwivedi et al. 2013). Thus there is a demand for gluten-free bread. In this aspect, cereals based gluten-free flour enriched with legumes have been a choice to develop bread, especially for the consumers carrying the celiac disease.

In India and Africa's semi-arid and arid regions, pearl millet is a staple food (Maktouf, Jeddou, Moulis, Hajji, Remaud-Simeon, \& Ellouz-Ghorbel, 2016). India is the world's biggest producer of pearl millet, wherein 9.8 million hectares of the area the crop is cultivated (Siroha, Sandhu, \& Kaur, 2016). It has a good amount of carbohydrates, dietary protein, fat, vitamins, and minerals. It has high lipid levels, well-balanced and high-quality protein, and a variety of phenolic compounds that are beneficial for health (Maktouf et al., 2016). Apart from lysine deficiency, it has an outstanding amino acid profile (Burton, Wallace, \& Rachie, 1972). It has anti-ulcerative, antioxidant, hypoglycemic, and hypocholesterolemic properties. Because of these health-promoting and nutritional properties, it is extensively used in bakery and snack food products (Maktouf et al., 2016). Also, various researchers have reported the use of pearl millet flour or pearl millet based composite flour for preparation of bread (Maktouf et al., 2016; Nami, Gharekhani, Aalami, \& Hejazi, 2019; Sawaya, Khalil, \& Safi, 1984).

Althogth the legume production has increased with time but agricultural legume species is currently underexploited (Cernay, Pelzer, \& Makowski, 2016). Thus the food researchers and industries have been constantly working for the application of legumes for the development of food products with superior nutrition value (Bhol \& Bosco, 2014; Miñarro, Albanell, Aguilar, Guamis, \& Capellas, 2012). Legumes contain a high level of lysine. So in a cereal-based diet, the lysine deficiency can be complemented by incorporating legumes into cereal foods (Kohajdová, Karovičová, \& Magala, 2013). Mung beans and red lentils are regarded as good sources of protein among legumes. They are rich in minerals like iron, manganese, calcium, and zinc; and vitamins particularly thiamine, riboflavin, and niacin along with antioxidants and polyphenols (Kohajdová et al., 2013). Various researchers have reported the use of legumes (lentil, bean, chickpea) mixed with wheat flour for preparation of bread (Rizzello, Calasso, Campanella, De Angelis, \& Gobbetti, 2014; Turfani, Narducci, Durazzo, Galli, \& Carcea, 2017; Rifna \& Dwivedi, 2020). However, till now no studies have reported the use of red lentil and mung bean flour with pearl millet flour for preparing gluten bread. Also, it is essential to optimize the proportion of the legumes and pearl millet flour for preparing bread of good quality.

Mixture design is a statistical tool that is used for studying the functions of ingredients and their interaction effect on responses along with the optimization of ingredients during new product development (Sarteshnizi, Hosseini, Bondarianzadeh, \& Colmenero, 2015). Among various types of mixture designs, the D-optimal mixture design combined with Numerical Optimization (DMD$\mathrm{NO}$ ) has been used by various researchers for ingredients optimization (Afshari et al., 2015; Shiby, Radhakrishna, \& Bawa, 2013; Shrivastava \& Chakraborty, 2018). Recently, Artificial Neural Network (ANN) coupled with Genetic Algorithm (GA) has evolved as a multivariate optimization technique in food processing (Chakraborty \& Shrivastava, 2019). ANN is a popular modeling technique which solves linear and non-linear problems of multivariate regression (Xi, Xue, Xu, \& Shen, 2013:Jerome, Singh \& Dwivedi, 2019) while GA which imitates the concept of biological evolution is a powerful tool for solving the optimization problems (Mukhopadhyay, Mishra, Goswami, \& Majumdar, 2015). Various processes have been optimized using ANN-GA combined technology (Dash \& Das, 2019; Kalathingal, Basak, \& Mitra, 2019; Xi et al., 2013); however, this technique has not been used yet for ingredient optimization for new product development. Therefore, both DMD-NO and ANN-GA techniques have been used and compared in this study for optimizing the composition of flours for the preparation of gluten-free bread.

\section{MATERIALS AND METHODS}

\section{Material procurement}

Pearl millet (Pennisetum glaucum) flour (8.9 \% moisture content), red lentil (Lens culinaris) and mung bean (Vigna radiata) were bought from the local market of Rourkela, Odisha, India. Wet yeast was procured from a local bakery in Rourkela, Odisha, India. Xanthan gum was purchased from Merck, India. 


\section{Preparation of legume flours}

Mung beans and red lentils samples were cleaned properly by washing with water and dried at $50 \pm 2{ }^{\circ} \mathrm{C}$ for 12 hours using a hot air oven (Model: K1-181, Khera instruments, India) (El-Adawy, Rahma, El-Bedawey, \& El-Beltagy, 2003). The dried samples were then ground using a mixer grinder (Model: GX-1, Bajaj, India) and passed through a $0.25 \mathrm{~mm}$ sieve. The prepared red lentils flour $(9.6 \%$ moisture content) and mung beans flour ( $9.1 \%$ moisture content) were kept in polythene zipper bags until used for the formulation of composite flour.

\section{D-optimal mixture design (DMD)}

D-optimal mixture design was used to find the different compositions of composite flour for the preparation of bread. Pearl millet flour (PMF), red lentils flour (RLF) and mung bean flour (MBF) was taken as the mixture components for the design of experiments. The ranges of these three components along with their coded values are provided in Table 1 . The summation of smallest coded value of first mixture component and largest coded value of other two mixture components is one. Similarly, the summation of largest coded value of first mixture component and highest coded value of other two mixture components is one. The three components constitute $100 \mathrm{~g}$ for each run to form composite flour. From this design, 14 number of runs were obtained, which are shown in Table 2. Among these 14 runs, the run 1 and 3,2 and 5, 4 and 8,6 and 14 are similar. The responses measured were the hardness of crumb $(\mathrm{N})\left(\mathrm{Y}_{1}\right)$, the total color change $(\Delta \mathrm{E})$ in the crust $\left(\mathrm{Y}_{2}\right)$ and the crumb $\left(\mathrm{Y}_{3}\right)$, and bread's specific volume $\left(\mathrm{cm}^{3} \cdot \mathrm{g}^{-1}\right)$ $\left(\mathrm{Y}_{4}\right)$.

A quadratic Scheffé mix model (Equation 1) was used to fit the actual values of responses. This model was selected for evaluating the influence of individual mixture components as well as their interaction on responses. The analysis of variance (ANOVA) was carried out to find the significance of the model, the model terms and lack of fit. Also, the two components mixture graphs were plotted to find the influence of the mixture of two flours on responses

$$
\mathrm{Y}=\sum_{\mathrm{i}=1}^{\mathrm{q}} \beta_{\mathrm{i}} \mathrm{x}_{\mathrm{i}}+\sum_{\mathrm{i}<\mathrm{j}}^{\mathrm{q}-1} \sum_{\mathrm{j}}^{\mathrm{q}} \beta_{\mathrm{ij}} \mathrm{x}_{\mathrm{i}} \mathrm{x}_{\mathrm{j}}
$$

Where $\mathrm{Y}$ is the response, $\beta$ is the coefficient of model term, $\mathrm{x}$ is the mixture component and $\mathrm{q}$ is the number of mixture components.

Table 1 Ranges of mixture components with the coded values used for D-optimal mixture design.

\begin{tabular}{lcccc} 
Component & Type & Minimum & Maximum & Coded Low \\
\hline $\begin{array}{l}\text { A: Pearl millet flour } \\
\text { (g) }\end{array}$ & Mixture & 60.00 & 80.00 & $+0 \leftrightarrow 60.00$ \\
$\begin{array}{l}\text { B: Red lentil flour (g) } \\
\begin{array}{l}\text { C: Mung bean flour } \\
\text { (g) }\end{array}\end{array}$ & Mixture & 15.00 & 25.00 & $+0 \leftrightarrow 15.00$ \\
& & 5.00 & 15.00 & $+0 \leftrightarrow 5.00$ \\
\cline { 2 - 4 } & & Total $=$ & 100.00 & $\begin{array}{c}\text { L_Pseudo } \\
\text { Coding }\end{array}$ \\
\hline
\end{tabular}

\section{Preparation of bread}

The bread was developed using the straight-dough technique approved by the AACC (international, 2000). Composite flour $(100 \mathrm{~g})$, water $(80 \mathrm{ml})$ and other estimated raw materials such as salt $(1.75 \mathrm{~g})$, sugar $(6 \mathrm{~g})$, wet yeast $(10 \mathrm{~g})$, and xanthan gum $(0.2 \mathrm{~g})$ were used to prepare the bread batter. Xanthan gum was mixed in the flour to enhance the viscoelastic properties of the dough (Shrivastava \& Chakraborty, 2018: Dwivedi et al., 2020; Mishra N et al., 2020). The bread was baked at $180^{\circ} \mathrm{C}$ for $45 \mathrm{~min}$ in a baking oven.

Table 2 Combinations of mixture components obtained from D-optimal mixture design and measured responses.

\begin{tabular}{|c|c|c|c|c|c|c|c|}
\hline \multirow[b]{2}{*}{ Run } & \multicolumn{3}{|c|}{ Components } & \multicolumn{4}{|c|}{ Responses } \\
\hline & $\begin{array}{l}\text { A:Pearl millet } \\
\quad \text { flour }(\mathrm{g})\end{array}$ & $\begin{array}{c}\text { B:Red lentil } \\
\text { flour } \\
(\mathrm{g})\end{array}$ & $\begin{array}{l}\text { C:Mung bean } \\
\text { flour } \\
(\mathrm{g})\end{array}$ & $\begin{array}{l}\text { Hardness } \\
\text { (N) }\end{array}$ & $\begin{array}{l}\text { Total color change } \\
\text { in crust }\end{array}$ & $\begin{array}{c}\text { Total color } \\
\text { change in crumb }\end{array}$ & $\begin{array}{l}\text { Specific volume } \\
\left(\mathrm{cm}^{3} / \mathrm{g}\right)\end{array}$ \\
\hline 1 & 70.00 & 15.00 & 15.00 & $9.55 \pm 0.31$ & $9.65 \pm 0.20$ & $4.46 \pm 0.17$ & $1.51 \pm 0.07$ \\
\hline 2 & 60.00 & 25.00 & 15.00 & $9.01 \pm 0.23$ & $8.59 \pm 0.23$ & $4.21 \pm 0.09$ & $1.58 \pm 0.06$ \\
\hline 3 & 70.00 & 15.00 & 15.00 & $9.55 \pm 0.31$ & $9.65 \pm 0.20$ & $4.46 \pm 0.17$ & $1.51 \pm 0.07$ \\
\hline 4 & 70.00 & 25.00 & 5.00 & $8.47 \pm 0.32$ & $7.31 \pm 0.29$ & $2.70 \pm 0.07$ & $1.52 \pm 0.09$ \\
\hline 5 & 60.00 & 25.00 & 15.00 & $9.01 \pm 0.23$ & $8.59 \pm 0.23$ & $4.21 \pm 0.09$ & $1.58 \pm 0.06$ \\
\hline 6 & 80.00 & 15.00 & 5.00 & $13.19 \pm 0.24$ & $11.02 \pm 0.19$ & $5.71 \pm 0.21$ & $1.25 \pm 0.06$ \\
\hline 7 & 75.00 & 20.00 & 5.00 & $9.32 \pm 0.10$ & $9.74 \pm 0.21$ & $4.24 \pm 0.11$ & $1.37 \pm 0.07$ \\
\hline 8 & 70.00 & 25.00 & 5.00 & $8.47 \pm 0.32$ & $7.31 \pm 0.29$ & $2.70 \pm 0.07$ & $1.52 \pm 0.09$ \\
\hline 9 & 65.00 & 25.00 & 10.00 & $7.26 \pm 0.21$ & $7.98 \pm 0.22$ & $3.22 \pm 0.07$ & $1.66 \pm 0.09$ \\
\hline 10 & 75.00 & 15.00 & 10.00 & $10.53 \pm 0.11$ & $10.65 \pm 0.26$ & $5.08 \pm 0.12$ & $1.41 \pm 0.10$ \\
\hline 11 & 72.50 & 20.00 & 7.50 & $9.63 \pm 0.24$ & $9.42 \pm 0.23$ & $4.36 \pm 0.15$ & $1.45 \pm 0.08$ \\
\hline 12 & 65.00 & 20.00 & 15.00 & $9.22 \pm 0.14$ & $8.38 \pm 0.15$ & $3.73 \pm 0.10$ & $1.54 \pm 0.04$ \\
\hline 13 & 70.00 & 20.00 & 10.00 & $8.35 \pm 0.19$ & $8.99 \pm 0.13$ & $3.69 \pm 0.14$ & $1.55 \pm 0.06$ \\
\hline 14 & 80.00 & 15.00 & 5.00 & $13.19 \pm 0.24$ & $11.02 \pm 0.19$ & $5.71 \pm 0.21$ & $1.25 \pm 0.06$ \\
\hline
\end{tabular}

Results are presented as mean \pm standard deviation of three replications.

\section{Measurement of responses}

\section{Hardness of crumb}

The hardness of the crumb of the bread samples was measured using a TA-RTKIT texture analyzer (Brookfield Engineering Labs. Inc.). A cylindrical probe (TA5) of $12.7 \mathrm{~mm}$ diameter in the texture analyzer was set as follows: TPA; trigger load: $0.10 \mathrm{~N}$; the speed of test: $0.7 \mathrm{~mm} . \mathrm{s}^{-1}$; return speed: $0.7 \mathrm{~mm} . \mathrm{s}^{-1}$; data acquisition rate: 50 points per second. The maximum force was noted as the hardness, which was obtained during the first compression cycle.

\section{Total color change}

A Hunter Lab's Colorimeter (ColorFlex EZ, Hunter Associates Laboratory Inc. USA) was used to measure the surface color of crumb and crust. The total change in color $(\Delta \mathrm{E})$ was determined using Equation 2.

$$
\Delta E=\sqrt{\left(L-L_{0}\right)^{2}+\left(a-a_{0}\right)^{2}+\left(b-b_{0}\right)^{2}}
$$

Where $\mathrm{L}$ is the lightness, $\mathrm{a}$ is redness, and $\mathrm{b}$ is yellowness index, respectively, and the suffix ' 0 ' denotes the control sample, i.e., the unbaked dough (Shrivastava \& Chakraborty, 2018; Tripathi et al., 2017; Madhuresh et al. 2013).

\section{Specific volume}

The bread loaves were weighed after baking for two hours. Bread's volume was determined using the method of rapeseed displacement, and bread's specific volume $\left(\mathrm{cm}^{3} \cdot \mathrm{g}^{-1}\right)$ was measured using the method prescribed by AACC (international, 2000).

\section{ANN modeling and GA optimization}

ANN of feed-forward nature with back-propagation learning algorithm was adopted in this work by using MATLAB (Version 2019a, Mathworks Inc.). The network comprises an input layer, an output layer, and a single hidden layer. The input and output layer had three and four neurons, respectively. Using a trial and error method, the number of neurons in the hidden layer was determined. Levenberg-Marquardt back-propagation (LM) algorithm was used to train the network. The transfer function used for neurons of the hidden layer and output layer were hyperbolic tangent sigmoid (tansig) and linear (purelin), respectively 
(Shen, Wang, \& Li, 2007). The data obtained from the D-optimal mixture design were also used for the development of the ANN model. The data were randomly divided into $70 \%, 15 \%$ and $15 \%$ for training, validation and testing of the network, respectively. Maximum percentage of data sets were allotted for training the model to obtain best possible values of neural network parameters, i.e., weight and bias values. The weights and biases values obtained after completion of training were used in Equation 3 to predict the value of responses.

$$
\mathrm{Y}=\text { purelin }\left(\mathrm{W} \times \operatorname{tansig}\left(\mathrm{U} \times \mathrm{X}_{\mathrm{i}}+\mathrm{TH}\right)+\mathrm{TO}\right)
$$

Where $X_{i}$ (i:1-3) is the input parameters (mixture components; $X_{1}$ : Pearl millet flour, $\mathrm{X}_{2}$ : Red lentil flour, and $\mathrm{X}_{3}$ : Mung bean flour), $\mathrm{Y}$ is the outputs of the network (responses). $\mathrm{U}$ is the weight of interconnecting lines between the input and hidden layer, $\mathrm{W}$ is the weight of interconnecting lines between the hidden and output layer. Biases of hidden and output layer's neurons are TH and TO, respectively.

The ANN model's performance was explained by statistical parameters like the correlation coefficient (R) and mean squared error (MSE) value (Simić et al., 2016).

The GA toolbox in MATLAB (Version 2019a, Mathworks Inc.) was used for performing optimization. A fitness function (F) was developed with the goal of minimizing hardness $\left(\mathrm{Y}_{1}\right)$, total color change in crust $\left(\mathrm{Y}_{2}\right)$, total color change in crumb $\left(\mathrm{Y}_{3}\right)$, and maximizing the specific volume $\left(\mathrm{Y}_{4}\right)$ with the constraint that the sum of three input parameters must be 100. These goals were achieved by maximizing the developed fitness function (Equation 4). The GA parameters were chosen for optimization were: feasible population creation function with population size of 50, rank ftness scaling function, roulette selection function, crossover fraction of 0.7 , scattered crossover function, adaptive feasible mutation function.

$\mathrm{F}=\frac{1}{1+\mathrm{Y}_{1}}+\frac{1}{1+\mathrm{Y}_{2}}+\frac{1}{1+\mathrm{Y}_{3}}+\mathrm{Y}_{4}$

\section{Models comparison}

The ANN model and D-optimal mixture designed models (MDM) were compared based on three statistical parameters, namely, mean squared error (MSE), absolute average deviation (AAD) and coefficient of determination $\left(\mathrm{R}^{2}\right)$ The mathematical expression for computing these parameters is given in Equation 5-7.

$\mathrm{MSE}=\frac{\sum_{\mathrm{i}=1}^{\mathrm{n}}\left(\mathrm{Y}_{\mathrm{a}}-\mathrm{Y}_{\mathrm{p}}\right)^{2}}{\mathrm{n}}$

$\mathrm{AAD}=\left[\frac{\sum_{\mathrm{i}=1}^{\mathrm{n}}\left(\frac{\left|\mathrm{Y}_{\mathrm{p}}-\mathrm{Y}_{\mathrm{a}}\right|}{\mathrm{Y}_{\mathrm{a}}}\right)}{\mathrm{n}}\right] \times 100$

$\mathrm{R}^{2}=1-\frac{\sum_{\mathrm{i}=1}^{\mathrm{n}}\left(\mathrm{Y}_{\mathrm{p}}-\mathrm{Y}_{\mathrm{a}}\right)^{2}}{\sum_{\mathrm{i}=1}^{\mathrm{n}}\left(\mathrm{Y}_{\mathrm{a}}-\mathrm{Y}_{\mathrm{m}}\right)^{2}}$

Where $\mathrm{n}$ is the total number of experiments, $Y_{a}$ and $Y_{p}$ are the actual and predicted value of responses, respectively, and $\mathrm{Y}_{\mathrm{m}}$ is the mean of actual values of response.

\section{Proximate composition}

Proximate analysis of the bread prepared using the optimum composition of flours obtained from D-optimal mixture design (numerical optimization) and ANN-GA method was carried out. AOAC methods were followed to determine protein, fat, ash, and fiber content. Carbohydrate content was calculated using the method of difference (AOAC., 1990).

\section{Sensory evaluation}

A panel of 15 individuals comprising of 8 males and 7 females were selected for the sensory evaluation. The bread was prepared using the optimum composition of flours obtained from D-optimal mixture design (Sample 1) and ANN-GA (Sample 2) method. A nine-point Hedonic scale was applied to score various sensory parameters like aroma, taste, color, and overall acceptability. Panelists were informed about the score sheet, the scoring process, and the chosen quality attributes for sensory analysis before evaluation.

\section{RESULTS AND DISCUSSION}

D-optimal mixture design combined with Numerical optimization (DMDNO)

\section{Hardness $(\mathrm{N})$ of the crumb}

The actual values of crumb hardness for each of the 14 experiments have been tabulated in Table 2. It ranged from $7.26 \pm 0.21 \mathrm{~N}$ to $13.19 \pm 0.24 \mathrm{~N}$. The minimum hardness $(7.26 \pm 0.21 \mathrm{~N})$ was observed for the bread prepared using PMF of $65 \mathrm{~g}$, RLF of $25 \mathrm{~g}$, and MBF of $10 \mathrm{~g}$. A similar harness of crumb hardness was reported for the bread developed from millet based composite flour (Singh, Mishra, \& Mishra, 2012). In order to predict the crumb's hardness, the Doptimal mixture design suggested a quadratic Scheffé model given in Equation 8.

Hardness $=13.08 \mathrm{~A}+7.85 \mathrm{~B}+14.25 \mathrm{C}-8.68 \mathrm{AB}-15.79 \mathrm{AC}-8.27 \mathrm{BC}$

Where, A, B and C are the coded values of mixture components (Table 1). The ANOVA result for the obtained model is given in Table 3. The model's Fvalue of 23.3 suggested that the model is significant. The normal probability and residuals vs. run plot were also used to analyze the relevance of the model. The normal probability plot specifies whether the residuals follow a normal distribution, thereby following the straight line. The residuals vs. run plot looks for lurking factors that might have affected the response during the experiment. A random scatter on the residuals vs. run plot is desirable. The straight-line trend in the normal probability plot (Figure 1(a)) and randomly scattered of data in residual vs. run plot (Figure 1(b)) confirmed the relevance of the model. The $\mathrm{R}^{2}$ value of 0.935 confirmed the good fit of the model to the actual values. The plot of predicted vs. actual values is shown in Figure 1(c). Also, the difference between adjusted $\mathrm{R}^{2}(0.895)$ and predicted $\mathrm{R}^{2}(0.808)$ was less than 0.2 , indicating the reasonable agreement between them. Further, the insignificant lack of fit ( $\mathrm{F}$ value of 1.65$)$ validated the adequacy of the model

Table 3 ANOVA for quadratic model for Hardness

\begin{tabular}{lcccccc}
\hline Source & $\begin{array}{c}\text { Sum of } \\
\text { Squares }\end{array}$ & df & $\begin{array}{c}\text { Mean } \\
\text { Square }\end{array}$ & $\begin{array}{c}\text { F- } \\
\text { value }\end{array}$ & p-value & \\
\hline Model & 35.34 & 5 & 7.07 & 23.30 & 0.0001 & significant \\
*Linear & 23.10 & 2 & 11.55 & 38.07 & 0.0001 & \\
Mixture & 0.7849 & 1 & 0.7849 & 2.59 & 0.1464 & \\
AB & 2.33 & 1 & 2.33 & 7.69 & 0.0242 & \\
AC & 0.3707 & 1 & 0.3707 & 1.22 & 0.3012 & \\
BC & 2.43 & 8 & 0.3034 & & & \\
Residual & 1.51 & 4 & 0.3775 & 1.65 & 0.3204 & significant \\
Lack of Fit & 0.9171 & 4 & 0.2293 & & & \\
Pure Error & 37.77 & 13 & & & & \\
Cor Total & & & & & & \\
\hline
\end{tabular}

* Inference for linear mixtures uses Type I sums of squares. 
(a)

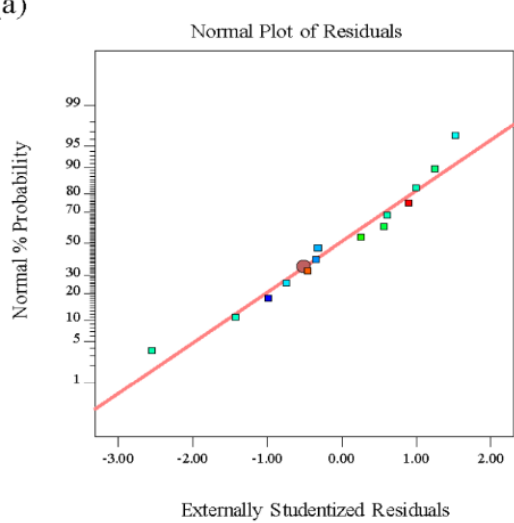

(d)

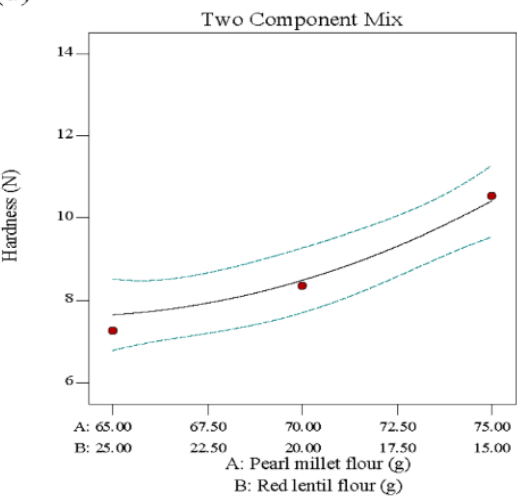

(b)

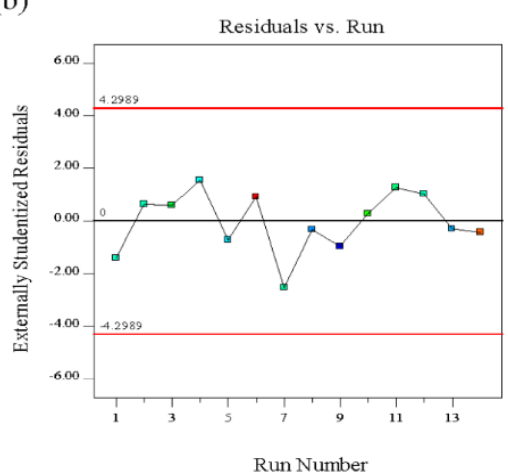

(e)

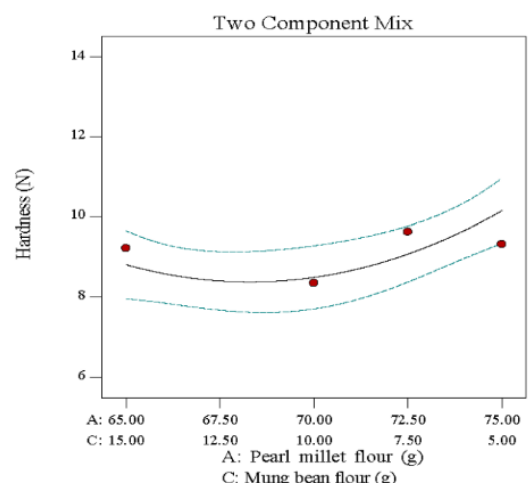

(c)

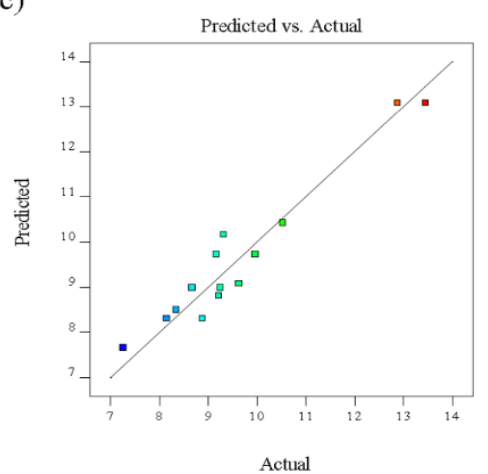

(f)

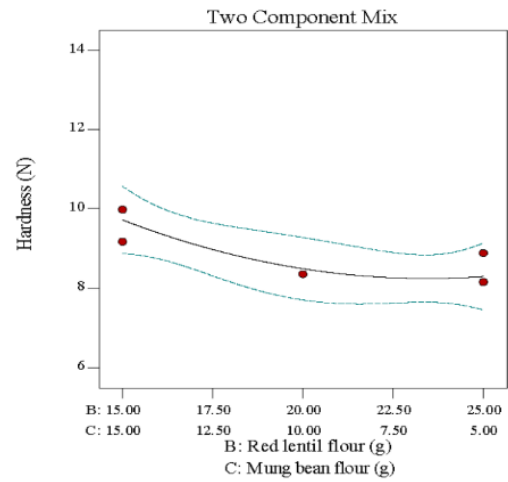

Figure 1 a: Normal plot of residuals, b: Residuals vs. Run plot, c: Model Predicted vs. Actual plot, d: Effect of pearl millet and red lentil flour on hardness, e: Effect of pearl millet and mung bean flour on hardness, f: Effect of red lentil and mung bean flour on hardness

In the model, A, B, C, and AC were the significant model terms. The linear terms had a positive correlation with hardness, whereas the interaction terms had a negative correlation. The model term $\mathrm{C}$ with a coefficient of +14.25 was found to be the most crucial factor which influences the hardness. The two components mixture graphs were plotted to evaluate the mixture of two flours on the hardness of crumb. The hardness increased slightly with the increase in the amount of PMF and decreased in RLF in the mixture. The minimum hardness was noticed when the mixture containing the lowest amount of PMF and the highest amount of RLF was used (Figure 1(d)). The mixture of PMF and BMF significantly influenced hardness. It showed a decreasing trend when PMF amount was increased up to $70 \mathrm{~g}$, and BMF was decreased up to $10 \mathrm{~g}$ in the mixture. Further decrease in BMF $5 \mathrm{~g}$ and an increase of PMF up to $75 \mathrm{~g}$ in the mixture increased hardness. The mixture of RLF and BMF did not have a significant effect; however, hardness decreased slightly with an increase in the RLF and decreased in the BMF amount in the mixture.

\section{Total color change $(\Delta E)$ in the crust}

In table 2, the actual values of $\Delta \mathrm{E}$ in the crust for each experiment in the design matrix is provided. It varied from $7.31 \pm 0.29$ to $11.02 \pm 0.19$. The Maximum color change in the crust was noticed in the bread prepared using PMF of $80 \mathrm{~g}$, RLF of $15 \mathrm{~g}$, and MBF of $5 \mathrm{~g}$, while the minimum was observed when PMF of $70 \mathrm{~g}$, RLF of $25 \mathrm{~g}$, and MBF of $5 \mathrm{~g}$ were used to prepare bread. A similar result in the total color change $(\Delta \mathrm{E})$ of the crust $(2.1$ to 5.90 was demonstrated for the bread prepared from wheat flour and fermented chickpea flour (Shrivastava \& Chakraborty, 2018). The model to predict the $\Delta \mathrm{E}$ in the crust is given in Equation 9.

$\Delta \mathrm{E}$ in crust $=11.09 \mathrm{~A}+4.30 \mathrm{~B}+6.65 \mathrm{C}-1.09 \mathrm{AB}+2.62 \mathrm{AC}+11.75 \mathrm{BC}$

The result of the ANOVA for the model are given in table 4. The model was found to be significant $(\mathrm{p}<0.0001)$, which was confirmed from its $\mathrm{F}$ value of 27.33. The relevance of the model was confirmed from the normal probability plot (Figure 2(a)), which showed a straight-line trend of data and residuals vs. run plot (Figure 2(b)), which showed a random scattered of the data. Figure 2 (c) shows the predicted vs. actual values of color change in the crust. The excellent fit of the actual values by the model was confirmed from the $\mathrm{R}^{2}$ value of 0.944 and an insignificant lack of fit ( $\mathrm{F}$ value of 5.19). Further, the predicted $\mathrm{R}^{2}(0.829)$ was in reasonable agreement with the adjusted $\mathrm{R}^{2}(0.910)$.

Table 4 ANOVA for quadratic model for total color change in crust

\begin{tabular}{lcccccc}
\hline Source & $\begin{array}{c}\text { Sum of } \\
\text { Squares }\end{array}$ & df & $\begin{array}{c}\text { Mean } \\
\text { Square }\end{array}$ & $\begin{array}{c}\text { F- } \\
\text { value }\end{array}$ & $\begin{array}{c}\text { p- } \\
\text { value }\end{array}$ & \\
\hline Model & 17.85 & 5 & 3.57 & 27.33 & 0.0001 & significant \\
*Linear & 14.52 & 2 & 7.26 & 55.57 & 0.0001 & \\
Mixture & & & & & \\
AB & 0.0125 & 1 & 0.0125 & 0.0956 & 0.7651 & \\
AC & 0.0642 & 1 & 0.0642 & 0.4917 & 0.5031 & \\
BC & 0.7480 & 1 & 0.7480 & 5.72 & 0.0437 & \\
Residual & 1.05 & 8 & 0.1307 & & & \\
Lack of Fit & 0.8764 & 4 & 0.2191 & 5.19 & 0.0699 & not \\
Pure Error & 0.1688 & 4 & 0.0422 & & & \\
Cor Total & 18.90 & 13 & & & & \\
\hline
\end{tabular}

* Inference for linear mixtures uses Type I sums of squares.

All the model terms except $\mathrm{AB}$ had a positive correlation with the $\Delta \mathrm{E}$ in the crust; however, only A, C, and BC were found to be significant model terms. The interaction term $\mathrm{BC}$ with a coefficient of +11.75 was the most critical factor that affects the $\Delta \mathrm{E}$ in the crust followed by $\mathrm{A}$ and $\mathrm{B}$. The influence of the interaction of two flours on the $\Delta \mathrm{E}$ in the crust is shown by plotting two components mixture graphs. The $\Delta \mathrm{E}$ in the crust increased with increasing the amount of PMF and decreasing the amount of RLF. The minimum color change was observed when the lowest amount of PMF and the highest amount of RLF were used together (Figure 2(d)). The mixture of PMF and MBF did not influence the $\triangle \mathrm{E}$ in the crust (Figure 2(e)). The $\Delta \mathrm{E}$ in the crust decreased with the increase in RLF and a decrease in BMF quantity. The mixture of the lowest amount of RLF and the highest amount of BMF resulted in maximum color change in the crust (Figure 2(f)). 
(a)

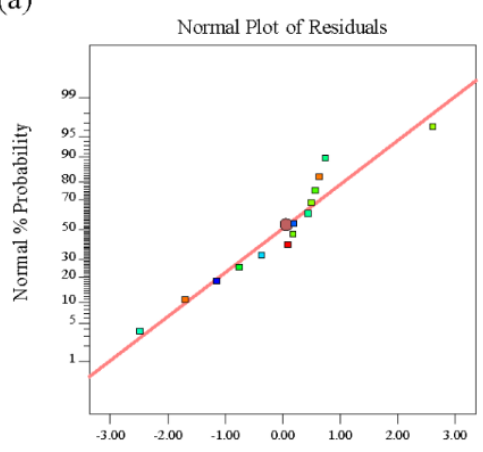

(d)

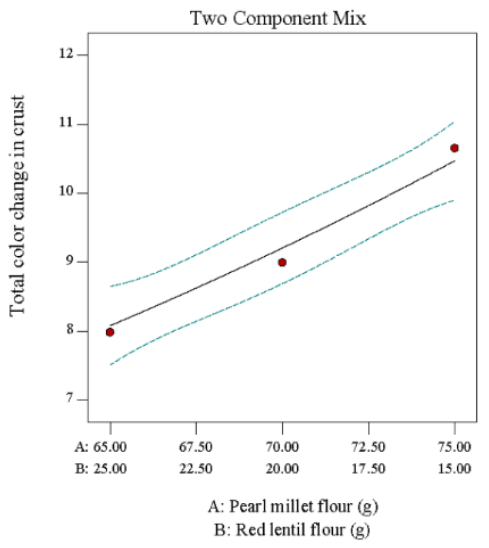

(b)

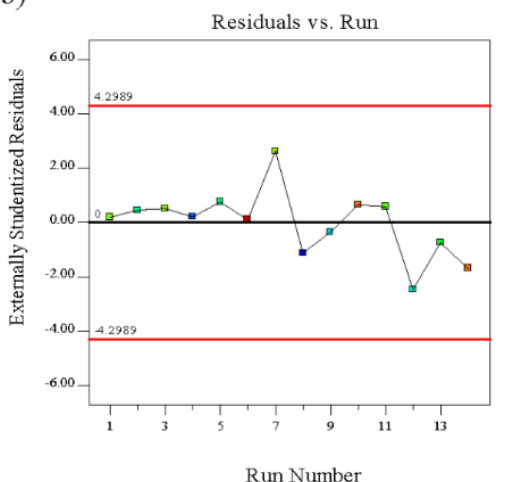

(e)

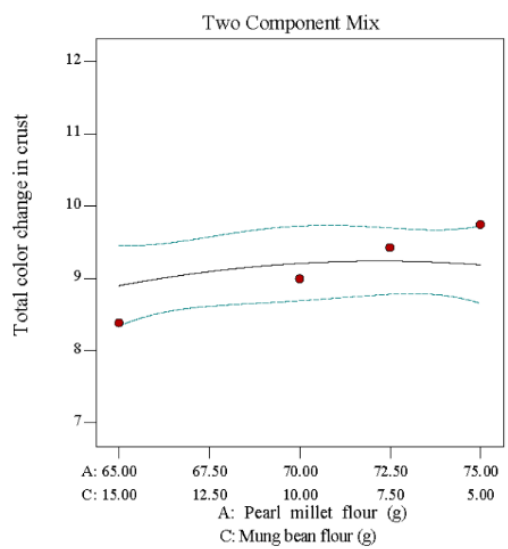

(c)

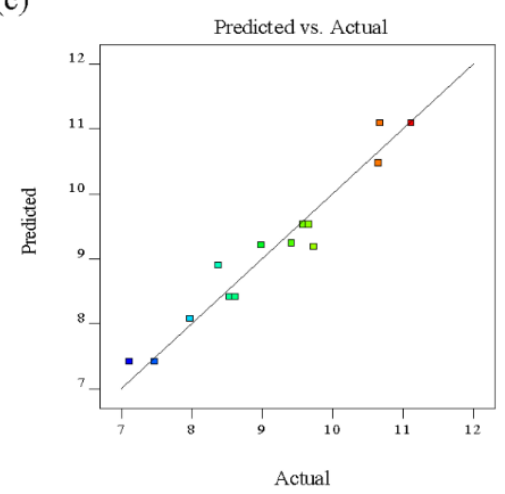

(f)

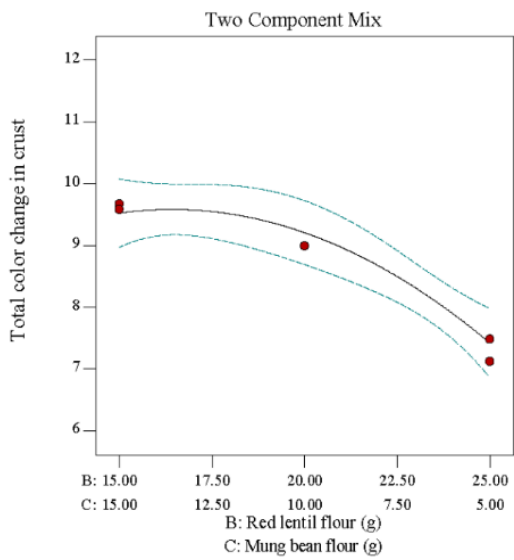

Figure 2 a: Normal plot of residuals, b: Residuals vs. Run plot, c: Model Predicted vs. Actual plot, d: Effect of pearl millet and red lentil flour on $\Delta \mathrm{E}$ in crust, e: Effect of pearl millet and mung bean flour on $\Delta \mathrm{E}$ in crust, f: Effect of red lentil and mung bean flour on $\Delta \mathrm{E}$ in crust

\section{Total color change $(\Delta \mathbf{E})$ in crumb}

The actual values of $\Delta \mathrm{E}$ in crumb for all the experiments are provided in Table 2. The minimum color change of $2.70 \pm 0.07$ was recorded when bread was prepared using PMF of $70 \mathrm{~g}$, RLF of $25 \mathrm{~g}$, and MBF of $5 \mathrm{~g}$. The maximum color change of $5.71 \pm 0.21$ measured for bread made using PMF of $80 \mathrm{~g}$, RLF of $15 \mathrm{~g}$, and MBF of $5 \mathrm{~g}$. Shrivastava and Chakraborty (2018) reported an analogus result in the total color change $(\Delta \mathrm{E})$ of crumb. The model for the prediction of $\Delta \mathrm{E}$ in crumb is given in Equation 10.

$\Delta \mathrm{E}$ in crumb $=5.75 \mathrm{~A}+1.44 \mathrm{~B}+3.78 \mathrm{C}-3.33 \mathrm{AB}-1.45 \mathrm{AC}+5.94 \mathrm{BC}$

The ANOVA result for the model is given in Table 5. The model's $\mathrm{F}$ value of 29.71 suggested that the model was significant. The relevance of the model was confirmed from the straight-line trend of data in normal probability plot (Figure $3(\mathrm{a})$ ), and random scattered of data in residuals vs. runs plot (Figure 3(b)). The plot for predicted vs. actual values of $\Delta \mathrm{E}$ in crumb is illustrated in Figure 3(c). A good fit of the model to actual values was confirmed from an $\mathrm{R}^{2}$ value of 0.948 and an insignificant lack of fit ( $F$ value of 3.31). Also, the predicted $R^{2}(0.854)$ and adjusted $R^{2}(0.917)$ were in the reasonable agreement since the difference between them was less than 0.2 .

Two components mixture graphs were plotted to visualize the influence of mixture containing two flours on the $\Delta \mathrm{E}$ in the crumb. The color change increased with the increase of the amount of PMF and a decrease in the amount of RLF in the mixture. The mixture containing the lowest amount of PMF and the highest amount of RLF resulted in minimum $\triangle \mathrm{E}$ in the crumb (Figure $3(\mathrm{~d})$ ). No significant change in $\Delta \mathrm{E}$ in the crumb was observed when the mixture had PMF and MBF only (Figure 3(e)). The $\triangle \mathrm{E}$ in the crumb decreased with the increase in RLF and decreased in BMF in the mixture. The minimum color change was observed when the mixture had the highest amount of RLF and the lowest amount of BMF (Figure 3(f)).

Table 5 ANOVA for quadratic model for total color change in crumb.

\begin{tabular}{lcccccc}
\hline Source & $\begin{array}{c}\text { Sum of } \\
\text { Squares }\end{array}$ & df & $\begin{array}{c}\text { Mean } \\
\text { Square }\end{array}$ & $\begin{array}{c}\text { F- } \\
\text { value }\end{array}$ & $\begin{array}{c}\text { p- } \\
\text { value }\end{array}$ & \\
\hline Model & 10.55 & 5 & 2.11 & 29.71 & $\begin{array}{c}< \\
0.0001\end{array}$ & significant \\
*Linear & 6.79 & 2 & 3.40 & 47.80 & 0.0001 & \\
Mixture & 0.1154 & 1 & 0.1154 & 1.63 & 0.2382 & \\
AB & 0.0197 & 1 & 0.0197 & 0.2773 & 0.6127 & \\
AC & 0.1914 & 1 & 0.1914 & 2.69 & 0.1393 & \\
BC & 0.5682 & 8 & 0.0710 & & & \\
Residual & 0.4365 & 4 & 0.1091 & 3.31 & 0.1363 & not \\
Lack of Fit & 0.1317 & 4 & 0.0329 & & & \\
Pure Error & 11.12 & 13 & & & & \\
Cor Total & 13 & & & & & \\
\hline
\end{tabular}

* Inference for linear mixtures uses Type I sums of squares. 
(a)

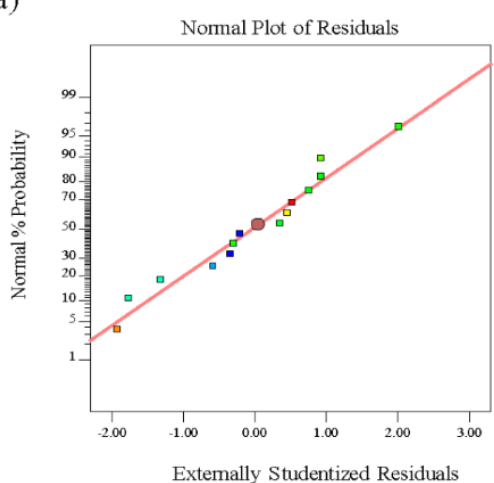

(d)

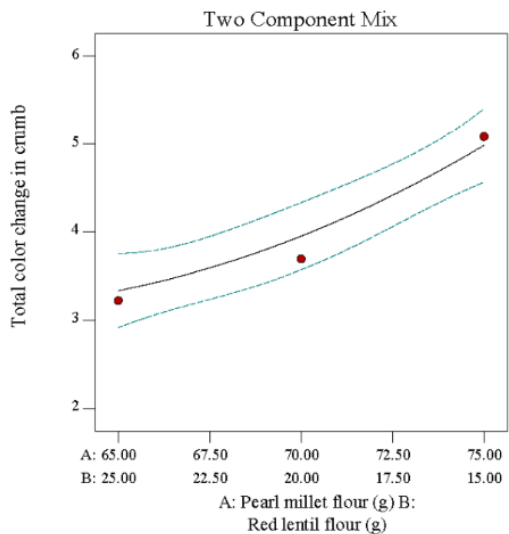

(b)

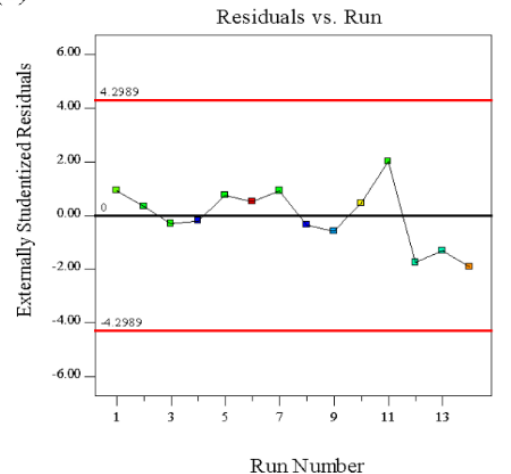

(e)

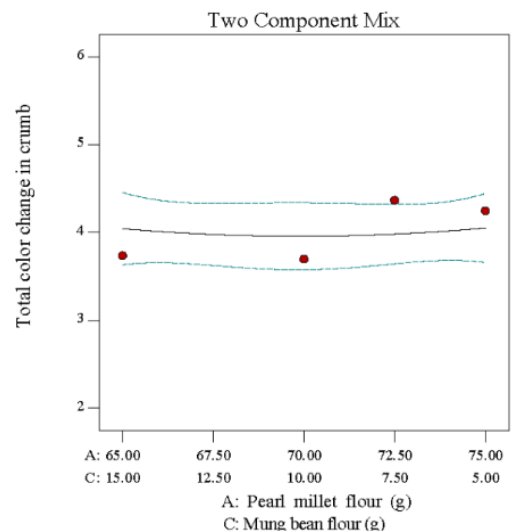

(c)

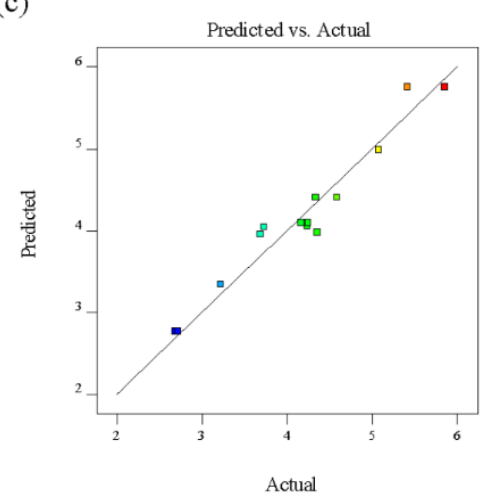

(f)

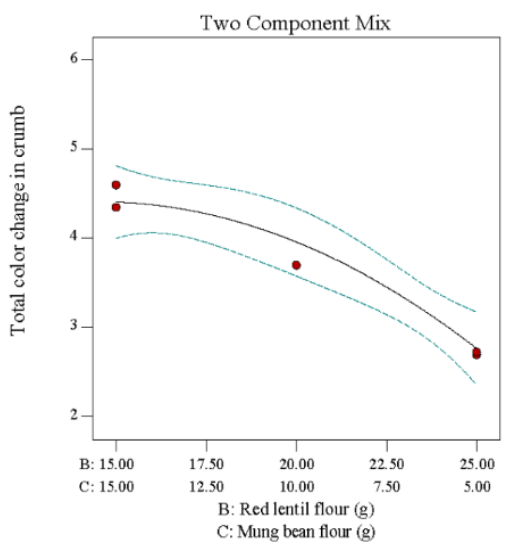

Figure 3 a: Normal plot of residuals, b: Residuals vs. Run plot, c: Model Predicted vs. Actual plot, d: Effect of pearl millet and red lentil flour on $\Delta \mathrm{E}$ in crumb, e: Effect of pearl millet and mung bean flour on $\Delta \mathrm{E}$ in crumb, f: Effect of red lentil and mung bean flour on $\Delta \mathrm{E}$ in crumb

\section{Specific volume $(\mathbf{S V})$}

The specific volume of the bread varied from $1.25 \pm 0.06 \mathrm{~cm}^{3} / \mathrm{g}$ to $1.66 \pm 0.09$ $\mathrm{cm}^{3} / \mathrm{g}$ (Table 2). Maximum SV was measured for bread prepared using PMF of $65 \mathrm{~g}$, RLF of $25 \mathrm{~g}$, and MBF of $10 \mathrm{~g}$. A similar value of specific volume was obtained for breaded prepared from millet based composite flour (Singh, Mishra, \& Mishra, 2012). The model to predict the value of SV is given in Equation 11 Specific volume $=1.24 \mathrm{~A}+1.87 \mathrm{~B}+1.11 \mathrm{C}-0.0991 \mathrm{AB}+1.23 \mathrm{AC}+0.4077 \mathrm{BC}$ (11)

Table 6 ANOVA for quadratic model for Specific volume.

\begin{tabular}{lcccccc}
\hline Source & $\begin{array}{c}\text { Sum of } \\
\text { Squares }\end{array}$ & df & $\begin{array}{c}\text { Mean } \\
\text { Square }\end{array}$ & $\begin{array}{c}\text { F- } \\
\text { value }\end{array}$ & $\begin{array}{c}\text { p- } \\
\text { value }\end{array}$ & \\
\hline Model & 0.1856 & 5 & 0.0371 & 16.70 & 0.0005 & significant \\
*Linear & 0.1549 & 2 & 0.0774 & 34.84 & 0.0001 & \\
Mixture & 0.0001 & 1 & 0.0001 & 0.0460 & 0.8355 & \\
AB & 0.0141 & 1 & 0.0141 & 6.33 & 0.0360 & \\
AC & 0.0009 & 1 & 0.0009 & 0.4054 & 0.5421 & \\
BC & 0.0178 & 8 & 0.0022 & & & \\
Residual & 0.0029 & 4 & 0.0007 & 0.1934 & 0.9297 & not \\
Lack of Fit & 0.0149 & 4 & 0.0037 & & & \\
Pure Error & 0.2033 & 13 & & & & \\
Cor Total & & & & & & \\
\hline
\end{tabular}

* Inference for linear mixtures uses Type I sums of squares.
Table 6 shows the results of the ANOVA for the model. The model was significant, with an $\mathrm{F}$ value of 16.70. The straight-line trend of data in the norma probability plot (Figure 4(a)) and randomly scattered data in residuals vs. runs plot (Figure 4(b)) confirmed the relevance of the model. Figure 4(c) illustrates the predicted vs. actual values of SV of bread. The $\mathrm{R}^{2}$ value of 0.912 indicated a decent fit of the model to actual values. Further, the adjusted $R^{2}(0.857)$ and predicted $R^{2}(0.723)$ were in reasonable agreement. The lack of fit was not significant ( $\mathrm{F}$ value of 0.1934 ), which confirmed the adequacy of the model.

The model terms A, B, C, and AC were found to be significant in the model. All the significant terms had a positive influence on the SV. The model term B, with a coefficient of +1.87 , was found to be the most significant factor that influences the SV. The effect of the mixture of two flours on the SV was assessed from the two components mixture graphs. SV decreased linearly with the increase in PMF and decreased in RLF content in the mixture. SV was maximum when the mixture had the lowest amount of PMF and the highest amount of RLF (Figure 4(d)). SV decreased non-linearly with the increase in PMF and decreased in MBF quantity in the mixture. SV was maximum when the highest amount of MBF and the lowest amount of PMF were used in the mixture. The mixture of RLF and BMF did not have any significant influence on SV (Figure 4(f)). 
(a)

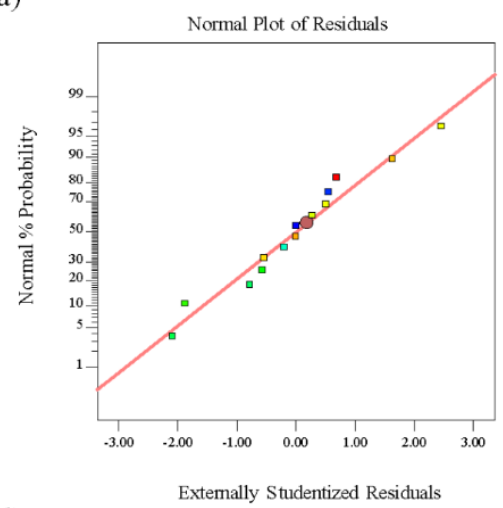

(d)

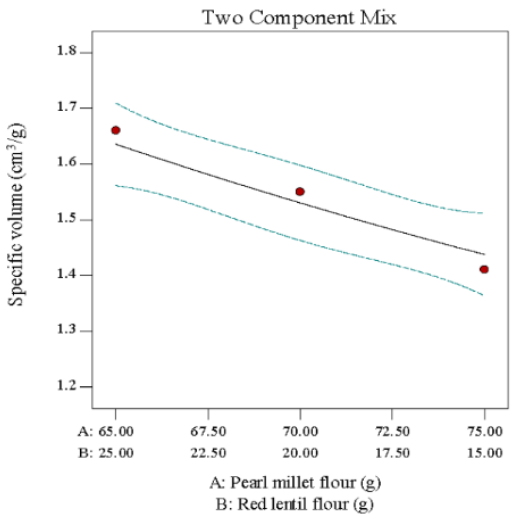

(b)

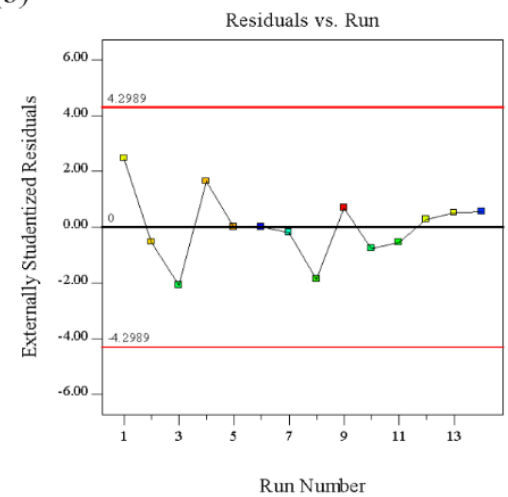

(e)

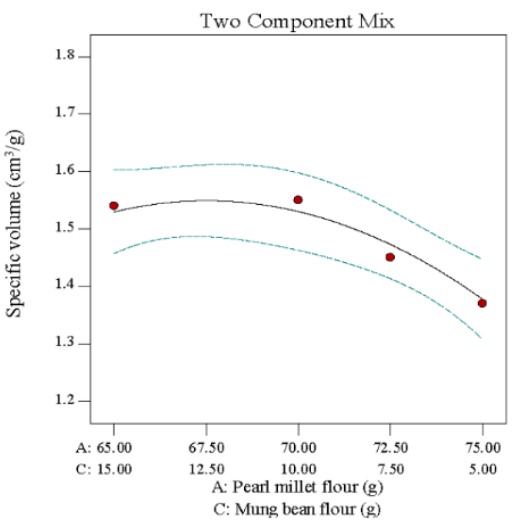

(c)

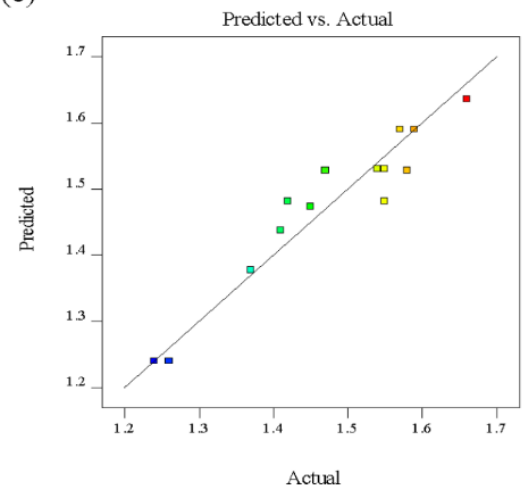

(f)

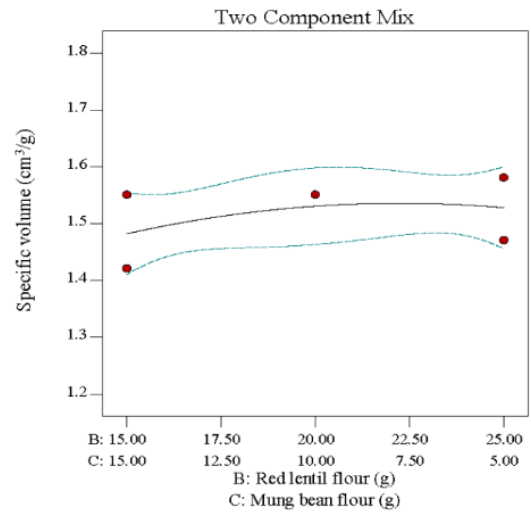

Figure 4 a: Normal plot of residuals, b: Residuals vs. Run plot, c: Model Predicted vs. Actual plot, d: Effect of pearl millet and red lentil flour on Specific volume (SV), e: Effect of pearl millet and mung bean flour on SV, f: Effect of red lentil and mung bean flour on SV

\section{Numerical optimization}

Numerical optimization in Design-Expert software was carried out for obtaining the optimum composition of composite flour. All three flours were kept in range while hardness, $\Delta \mathrm{E}$ in the crust, and $\Delta \mathrm{E}$ in crumb were minimized and the specific volume was maximized. The optimum composition obtained was 69.44 $\mathrm{g}$ of pearl millet flour, $21 \mathrm{~g}$ of red lentil flour and $9.56 \mathrm{~g}$ of mung bean flour. The values of hardness, $\Delta \mathrm{E}$ in the crust, $\Delta \mathrm{E}$ in crumb and specific volume at this composition predicted by the models were $8.28 \mathrm{~N}, 8.97,3.78$ and $1.54 \mathrm{~cm}^{3} / \mathrm{g}$, respectively. For validation of these, bread was prepared using an optimum composition of flours. The values of hardness, $\Delta \mathrm{E}$ in the crust, $\Delta \mathrm{E}$ in crumb and specific volume measured experimentally were $8.09 \pm 0.15 \mathrm{~N}, 8.88 \pm 0.13,3.85 \pm$ 0.09 , and $1.57 \pm 0.04 \mathrm{~cm}^{3} / \mathrm{g}$. These actual values of responses are in close correlation with the predicted values.

\section{Optimization using ANN-GA}

The experimental matrix along with the actual data of responses provided in table 2 was used for the development of the ANN model. Based on minimum MSE and maximum R-value of the training, validation and testing data set, six neurons in the single hidden layer of the network was taken. Thus, the architecture ANN model was three, six and four neurons in input, hidden and output layer, respectively (Figure 5).

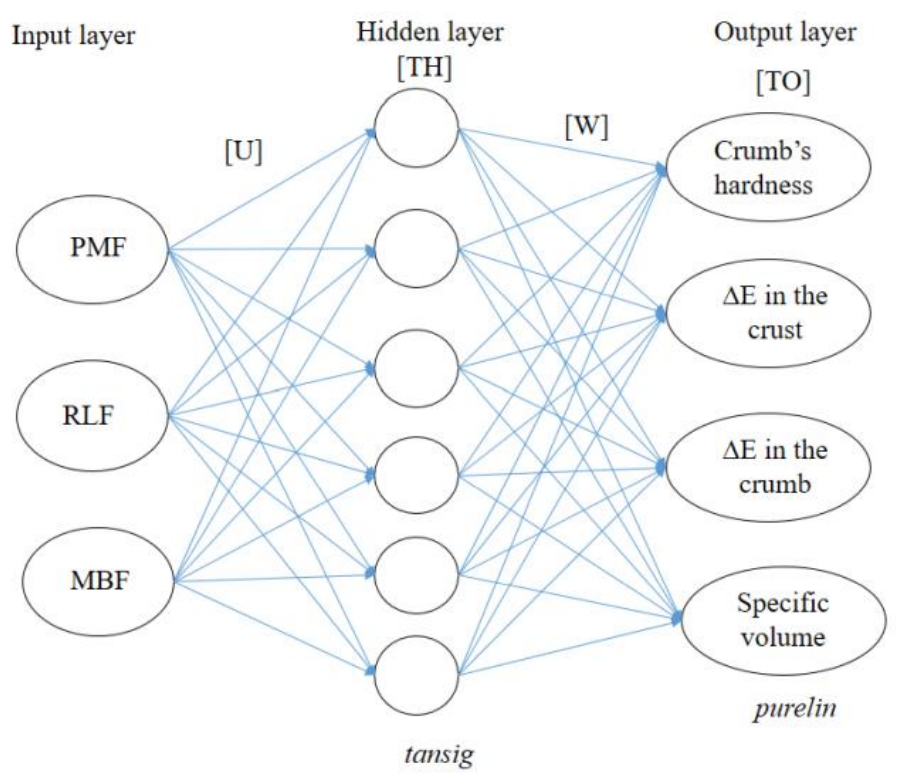

Figure 5 Architecture of the developed ANN model.

The best performance of the model was achieved at epoch 3 when the validation MSE was 0.1229. At this stage, the MSE value of training, validation and testing data set were lowest. The MSE of training and testing data set were 0.0179 and 0.0897, respectively. The closeness of MSE values between testing and training set confirmed the model's prediction accuracy for unseen data. Also, the value of correlation coefficient (R) for training, validation, testing, and all data set were $0.999,0.994,0.998$, and 0.998 , respectively. These values confirmed that there was an excellent agreement between the predicted and actual values of responses. The predicted vs. actual graph for each of the responses is given in Figure 6. 

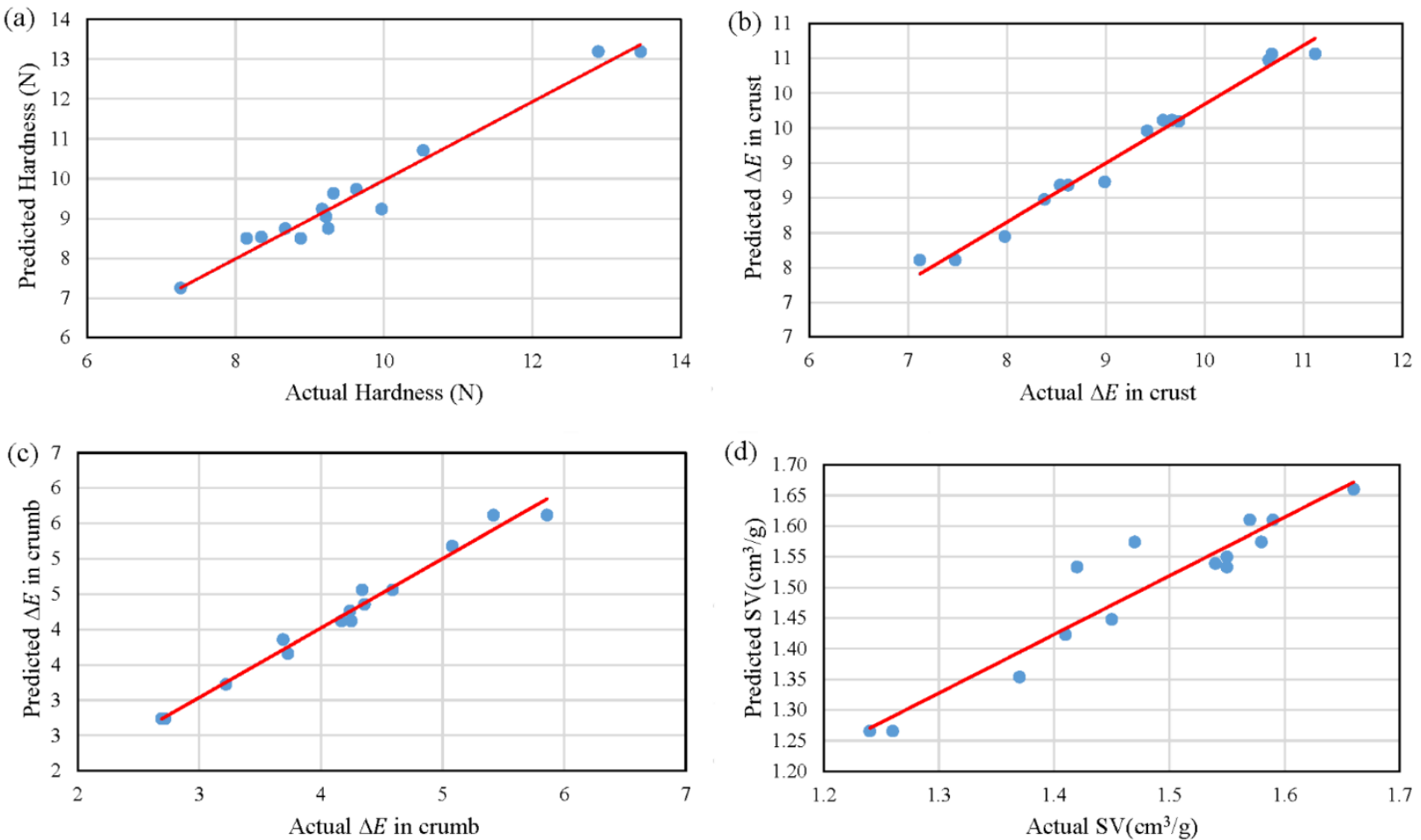

Figure 6 ANN predicted vs. actual values, a) Hardness (N), b) total color change in the crust, c) total color change in the crumb, d) specific volume $\left(\mathrm{cm}^{3} / \mathrm{g}\right)$. The weights and biases values of the ANN model are given in Equation 12-15.

$U=\left[\begin{array}{ccc}-1.4030 & -0.2734 & 1.6182 \\ 0.9545 & 3.3874 & -1.8779 \\ -0.8580 & 1.2094 & 2.8767 \\ 1.5876 & -0.1714 & 1.0873 \\ 0.7546 & 2.3171 & 0.4282 \\ 1.3393 & -1.7567 & 1.3085\end{array}\right]$

$T H=\left[\begin{array}{c}3.4543 \\ -2.9659 \\ 1.4629 \\ -0.0153 \\ 1.6206 \\ 2.6756\end{array}\right]$

$W=\left[\begin{array}{cccccc}-1.4038 & -1.3985 & -0.4847 & 0.7716 & 0.3186 & -2.0032 \\ 0.7745 & -0.2096 & -0.3159 & -0.3318 & -0.6339 & 0.4861 \\ 0.0910 & -0.7691 & -0.2797 & -0.3248 & -0.6316 & -0.2106 \\ 1.0703 & 0.1221 & 0.4828 & -0.3473 & -0.1457 & -0.1559\end{array}\right]$

$T O=\left[\begin{array}{c}1.5583 \\ -0.7939 \\ -0.0819 \\ -0.6212\end{array}\right]$

The developed ANN model was combined with GA for obtaining the optimum composition of composite flour. Pearl millet flour of $68.25 \mathrm{~g}$, red lentil flour of $23.12 \mathrm{~g}$ and mung bean flour of $8.63 \mathrm{~g}$ were determined to be the optimum composition. At this composition of flours, the values of hardness, $\Delta \mathrm{E}$ in the crust, $\Delta \mathrm{E}$ in crumb and specific volume predicted by the ANN model were 6.34 $\mathrm{N}, 8.56,3.51$, and $1.61 \mathrm{~cm}^{3} / \mathrm{g}$, respectively. The bread was prepared using the optimum composition of flours for validation of the optimization results. The value of hardness, $\Delta \mathrm{E}$ in the crust, $\Delta \mathrm{E}$ in crumb and specific volume determined experimentally were $7.21 \pm 0.12 \mathrm{~N}, 8.49 \pm 0.19,3.44 \pm 0.11$, and $1.65 \pm 0.06$ $\mathrm{cm}^{3} / \mathrm{g}$, respectively, which are very close to the predicted values.

\section{Comparison of ANN and DMD models}

The values of MSE, AAD, and $\mathrm{R}^{2}$ computed for each of the responses for both the DMD and ANN models are provided in table 7. A model is desirable when the MSE and AAD values are low while the $\mathrm{R}^{2}$ value is high. In terms of MSE and $\mathrm{R}^{2}$ values, the ANN model was found to be better than that of DMD models for all the responses except specific volume; however, the AAD values of the ANN model were found to be lower than DMD models for all the responses. In conclusion, the ANN model was superior to that of DMD models for the prediction of responses based on statistical parameters.

Table 7 Comparison of ANN and MDM models based on statistical parameters.

\begin{tabular}{lcccccc}
\hline \multirow{2}{*}{ Responses } & \multicolumn{2}{c}{ MSE } & \multicolumn{2}{c}{ AAD $(\%)$} & \multicolumn{2}{c}{$\mathbf{R}^{2}$} \\
\cline { 2 - 7 } & DMD & ANN & DMD & ANN & DMD & ANN \\
\hline Hardness & 0.1735 & 0.1025 & 3.93 & 2.68 & 0.935 & 0.963 \\
$\Delta$ E in crust & 0.0747 & 0.0528 & 2.45 & 1.86 & 0.944 & 0.980 \\
$\Delta$ E in crumb & 0.0404 & 0.0152 & 4.09 & 2.09 & 0.948 & 0.981 \\
Specific volume & 0.0012 & 0.0019 & 1.87 & 1.79 & 0.912 & 0.898 \\
\hline
\end{tabular}

DMD: D-optimal Mixture Designed; ANN: Artificial Neural Network; MSE Mean Squared Error; AAD: Absolute Average Deviation; $\Delta \mathrm{E}$ : Total color change

Table 8 Quality attributes of bread prepared using optimized composition of flours.

\begin{tabular}{lcc}
\hline Quality attributes & DMD-NO optimized & ANN-GA optimized \\
\hline Hardness (N) & $8.09 \pm 0.15^{\mathrm{b}}$ & $7.15 \pm 0.12^{\mathrm{a}}$ \\
$\Delta \mathrm{E}$ in crust & $8.88 \pm 0.13^{\mathrm{a}}$ & $8.49 \pm 0.19^{\mathrm{a}}$ \\
$\Delta \mathrm{E}$ in crumb & $3.85 \pm 0.09^{\mathrm{a}}$ & $3.44 \pm 0.11^{\mathrm{a}}$ \\
Specific volume $\left(\mathrm{cm}^{3} / \mathrm{g}\right)$ & $1.57 \pm 0.04^{\mathrm{a}}$ & $1.65 \pm 0.06^{\mathrm{b}}$ \\
Protein $(\%)$ & $16.50 \pm 0.38^{\mathrm{a}}$ & $16.63 \pm 0.28^{\mathrm{a}}$ \\
Fat $(\%)$ & $5.12 \pm 0.12^{\mathrm{b}}$ & $4.86 \pm 0.20^{\mathrm{a}}$ \\
Ash $(\%)$ & $3.57 \pm 0.04^{\mathrm{a}}$ & $4.02 \pm 0.06^{\mathrm{b}}$ \\
Fibre $(\%)$ & $3.66 \pm 0.13^{\mathrm{a}}$ & $4.23 \pm 0.21^{\mathrm{b}}$ \\
Carbohydrate $(\%)$ & $71.15 \pm 0.43^{\mathrm{b}}$ & $70.26 \pm 0.23^{\mathrm{a}}$ \\
\hline
\end{tabular}

Paired t-test: means in same row with different superscripts are significantly $(\mathrm{p}<$ $0.05)$ different.

The quality properties of bread prepared using the optimum composition of flours obtained using DMD-NO (Sample 1) and ANN-GA (Sample 2) techniques are presented in Table 8. A paired t-test was performed to find any significant difference $(p<0.05)$ between the quality properties of the two samples. A significant difference in crumb's hardness, specific volume, fat, ash, fiber and carbohydrate content was observed. Sample 2 had lower hardness, fat, and carbohydrate content and higher specific volume, protein, ash and fiber content than sample 1. Also, the total color change in the crust and crumb were minimum in sample 2. Thus, sample 2 i.e. the bread prepared using the optimum 
composition of flours obtained using the ANN-GA technique was better in terms of quality.

\section{Sensory evaluation}

The score of sensory attributes such as taste, color, aroma and overall acceptability of the bread prepared using the optimum composition of flours obtained using DMD (Sample 1) and ANN-GA (Sample 2) techniques are illustrated in Figure 7. No significant difference in sensory properties between both the samples was observed; however, sample 2 was slightly better than sample 1 in terms of all parameters. The color and aroma of sample 1 were in the "like moderately" category whereas for sample 2 they were in-between "like moderately" and "like very much" category in hedonic scale. The taste and overall acceptability got a low score for both the samples and they were in the "like slightly" category.

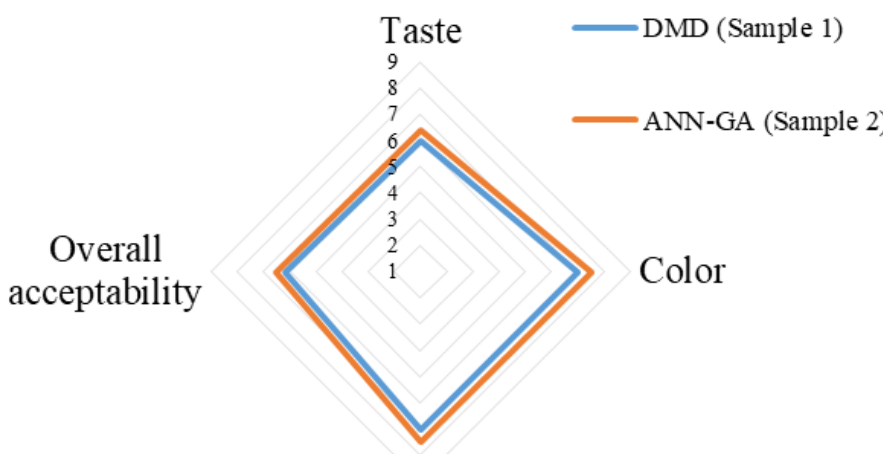

Aroma

Figure 7 Sensory properties of breads prepared using optimum composition flours obtained using DMD (Sample 1) and ANN-GA technique (Sample 2).

\section{CONCLUSION}

In this study, an effort was made to optimize the composition of flours that can be used for preparing gluten-free bread. For optimization, D-optimal mixture design (DMD) and ANN-GA technique were used. Models obtained using both the methods excellently fit the actual values of responses as confirmed from their high coefficient of determination values; however, the ANN model was found superior to DMD models based on statistical parameters. The PMF of $69.44 \mathrm{~g}$ of, RLF of $21 \mathrm{~g}$ and MLF of $9.56 \mathrm{~g}$ were the optimum composition flour obtained using the DMD method whereas using the ANN-GA technique, it was $68.25 \mathrm{~g}$ of PMF, $23.12 \mathrm{~g}$ of RLF and $8.63 \mathrm{~g}$ of MLF. The bread prepared using ANN-GA optimized flour had better quality properties. However, bread prepared using both compositions of flours fell in the "like slightly" category in terms of overall acceptability in the 9-point hedonic scale.

\section{REFERENCES}

Afshari, R., Hosseini, H., Khaksar, R., Mohammadifar, M. A., Amiri, Z. Komeili, R., \& Khaneghah, A. M. (2015). Investigation of the effects of inulin and $\beta$-glucan on the physical and sensory properties of low-fat beef burgers containing vegetable oils: Optimisation of the formulation using D-optima mixture design. Food technology and biotechnology, 53(4), 436-445 https://doi.org/10.17113/ftb.53.04.15.3980

AIBMA (2020, August 19). All India Bread Manufacturer's Association. https://www.aibma.com/industry.html

AOAC. (1990). Official methods of analysis of AOAC. Paper presented at the International.

Bhol, S., \& Bosco, S. J. D. (2014). Influence of malted finger millet and red kidney bean flour on quality characteristics of developed bread. LWT-Food Science and Technology, 55(1), 294-300. https://doi.org/10.1016/j.lwt.2013.08.012

Burton, G. W., Wallace, A., \& Rachie, K. (1972). Chemical Composition and Nutritive Value of Pearl Millet (Pennisetum typhoides (Burm.) Stapf and EC Hubbard) Grain 1. Crop Science, 12(2), 187-188. https://doi.org/10.2135/cropsci1972.0011183X001200020009x

Cernay, C., Pelzer, E., \& Makowski, D. (2016). A global experimental dataset for assessing grain legume production. Scientific data, 3(1), 1-20 https://doi.org/10.1038/sdata.2016.84

Chakraborty, S., \& Shrivastava, C. (2019). Comparison between multiresponserobust process design and numerical optimization: A case study on baking of fermented chickpea flour-based wheat bread. Journal of Food Process Engineering, 42(3), e13008. https://doi.org/10.1111/jfpe.13008

Dash, K. K., \& Das, S. K. (2019). Optimization of fluidized bed preconditioning for microwave puffed rice using integrated artificial neural network and genetic algorithm approach. Journal of Food Process Engineering, e13158. https://doi.org/10.1111/jfpe.13158

Deora, N. S., Deswal, A., Dwivedi, M., \& Mishra, H. N. (2014). Prevalence of coeliac disease in India: A mini review. Int J Latest Res Sci Technol, 3(10), 58 60.

Madhuresh, D., Mishra, H.N., Deora, N.S., Baik, O.D., Meda, V. (2013). A Response Surface Methodology (RSM) for optimizing the gluten free bread formulation containing hydrocolloid, modified starch and rice flour. The Canadian Society for Bioengineering (CSBE), 13-112.

Dwivedi, M., Chakraborty, S., Deora, N. S., \& Mishra, H. N. (2020). Use of Response Surface Methodology to Optimize the Formulation of Rice based Gluten Free Bread and Its Characterization. Research \& Reviews: Journal of Food Science and Technology, 3(2), 1-11. https://doi.org/10.37591/rrjofst.v3i2.2688

El-Adawy, T. A., Rahma, E. H., El-Bedawey, A. A., \& El-Beltagy, A. E. (2003) Nutritional potential and functional properties of germinated mung bean, pea and lentil seeds. Plant Foods for Human Nutrition, 58(3), 1-13. https://doi.org/10.1023/B:QUAL.0000040339.48521.75

Gallagher, E., Gormley, T., \& Arendt, E. K. (2004). Recent advances in the formulation of gluten-free cereal-based products. Trends in Food Science \& Technology, 15(3-4), 143-152. https://doi.org/10.1016/j.tifs.2003.09.012 International, A. (2000). Approved methods of analysis: AACC international St. Paul, MN.

Jerome, R. E., Singh, S. K., \& Dwivedi, M. (2019). Process analytical technology for bakery industry: A review. Journal of Food Process Engineering, 42(5), e13143.

Kalathingal, M. S. H., Basak, S., \& Mitra, J. (2019). Artificial neural network modeling and genetic algorithm optimization of process parameters in fluidized bed drying of green tea leaves. Journal of Food Process Engineering, e13128 https://doi.org/10.1111/jfpe.13128

Kaur, A. P. A. (2018). Gluten-free flat bread from sorghum: Quality characteristics. IJCS, 6(2), 1651-1656.

Kohajdová, Z., Karovičová, J., \& Magala, M. (2013). Effect of lentil and bean flours on rheological and baking properties of wheat dough. Chemical Papers, 67(4), 398-407. https://doi.org/10.2478/s11696-012-0295-3

Maktouf, S., Jeddou, K. B., Moulis, C., Hajji, H., Remaud-Simeon, M., \& Ellouz Ghorbel, R. (2016). Evaluation of dough rheological properties and bread texture of pearl millet-wheat flour mix. Journal of food science and technology, 53(4), 2061-2066. https://doi.org/10.1007/s13197-015-2065-Z

Miñarro, B., Albanell, E., Aguilar, N., Guamis, B., \& Capellas, M. (2012). Effect of legume flours on baking characteristics of gluten-free bread. Journal of Cereal Science, 56(2), 476-481. https://doi.org/10.1016/j.jcs.2012.04.012

Mishra, N., Tripathi, R., \& Dwivedi, M. (2020). DEVELOPMENT AND CHARACTERIZATION OF ANTIOXIDANT RICH WHEATGRASS CUPCAKE. Carpathian Journal of Food Science \& Technology, 12(3).

Mukhopadhyay, S., Mishra, H., Goswami, T., \& Majumdar, G. (2015). Neura network modeling and optimization of process parameters for production of chhana cake using genetic algorithm. International Food Research Journal, 22(2). Murakonda, S., \& Dwivedi, M. Powders from Fruit Waste. In Food Powders Properties and Characterization (pp. 155-168). Springer, Cham.

Nami, Y., Gharekhani, M., Aalami, M., \& Hejazi, M. A. (2019). Lactobacillusfermented sourdoughs improve the quality of gluten-free bread made from pearl millet flour. Journal of Food Science and Technology, 56(9), 4057-4067. https://doi.org/10.1007/s13197-019-03874-8

Rizzello, C. G., Calasso, M., Campanella, D., De Angelis, M., \& Gobbetti, M. (2014). Use of sourdough fermentation and mixture of wheat, chickpea, lentil and bean flours for enhancing the nutritional, texture and sensory characteristics of white bread. International journal of food microbiology, 180, 78-87. https://doi.org/10.1016/j.ijfoodmicro.2014.04.005

Rifna, E. J., \& Dwivedi, M. The Microbiological Safety of Food Powders. In Food Powders Properties and Characterization (pp. 169-193). Springer, Cham. Sarteshnizi, R. A., Hosseini, H., Bondarianzadeh, D., \& Colmenero, F. J. (2015) Optimization of prebiotic sausage formulation: Effect of using $\beta$-glucan and resistant starch by D-optimal mixture design approach. LWT-food Science and Technology, 62(1), 704-710. https://doi.org/10.1016/j.lwt.2014.05.014

Sawaya, W. N., Khalil, J. K., \& Safi, W. J. (1984). Nutritional quality of pearl millet flour and bread. Plant Foods for Human Nutrition, 34(2), 117-125.

Shen, C., Wang, L., \& Li, Q. (2007). Optimization of injection molding process parameters using combination of artificial neural network and genetic algorithm method. Journal of Materials Processing Technology, 183(2-3), 412-418 https://doi.org/10.1016/j.jmatprotec.2006.10.036

Shiby, V. K., Radhakrishna, K., \& Bawa, A. S. (2013). Development of wheyfruit-based energy drink mixes using D-optimal mixture design. International $\begin{array}{llll}\text { Journal of Food Science \& Technology, 48(4), 742-748. } & \end{array}$ https://doi.org/10.1111/ijfs.12022

Shrivastava, C., \& Chakraborty, S. (2018). Bread from wheat flour partially replaced by fermented chickpea flour: Optimizing the formulation and fuzzy analysis of sensory data. LWT, 90, 215-223 https://doi.org/10.1016/j.lwt.2017.12.019 
Simić, V. M., Rajković, K. M., Stojičević, S. S., Veličković, D. T., Nikolić, N. Č., Lazić, M. L., \& Karabegović, I. T. (2016). Optimization of microwaveassisted extraction of total polyphenolic compounds from chokeberries by response surface methodology and artificial neural network. Separation and
Purification

Technology,

160 ,

89-97.

https://doi.org/10.1016/j.seppur.2016.01.019

Singh, K., Mishra, A., \& Mishra, H. (2012). Fuzzy analysis of sensory attributes of bread prepared from millet-based composite flours. LWT-food Science and Technology, 48(2), 276-282. https://doi.org/10.1016/j.lwt.2012.03.026

Siroha, A. K., Sandhu, K. S., \& Kaur, M. (2016). Physicochemical, functional and antioxidant properties of flour from pearl millet varieties grown in India Journal of Food Measurement and Characterization, 10(2), 311-318 https://doi.org/10.1007/s11694-016-9308-1

Tripathi, R., Sharma, D., Dwivedi, M., Rizvi, S.I., \& Mishra, N. (2017) Wheatgrass incorporation as a viable strategy to enhance nutritional quality of an edible formulation, Annals of Phytomedicine 6(1): 68-75 https://doi.org/10.21276/ap.2017.6.1.10

Turfani, V., Narducci, V., Durazzo, A., Galli, V., \& Carcea, M. (2017). Technological, nutritional and functional properties of wheat bread enriched with

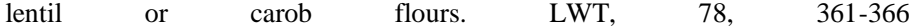
https://doi.org/10.1016/j.lwt.2016.12.030

Xi, J., Xue, Y., Xu, Y., \& Shen, Y. (2013). Artificial neural network modeling and optimization of ultrahigh pressure extraction of green tea polyphenols. Food chemistry, 141(1), 320-326. https://doi.org/10.1016/j.foodchem.2013.02.084 